\title{
Scleractinian corals recorded in the Argentinean Antarctic expeditions between 2012 and 2014, with comments on Flabellum (Flabellum) areum Cairns, 1982
}

\author{
Laura Schejter, ${ }^{1,2}$ Claudia S. Bremec ${ }^{2} \&$ Stephen D. Cairns ${ }^{3}$ \\ 1 Instituto Nacional de Investigación y Desarrollo Pesquero, Paseo Victoria Ocampo 1, 7600 Mar del Plata, Argentina \\ 2 Consejo Nacional de Investigaciones Científicas y Técnicas, Instituto de Investigaciones Marinas y Costeras, Mar del Plata, Argentina \\ ${ }^{3}$ Department of Invertebrate Zoology, National Museum of Natural History, Smithsonian Institution, Washington, DC 20560, USA
}

\begin{abstract}
Keywords
cold-water corals; Antarctica; range extension; bathymetric range extension; Scleractinia.

Correspondence

Laura Schejter, Instituto Nacional de Investigación y Desarrollo Pesquero, Paseo Victoria Ocampo 1, 7600 Mar del Plata, Argentina. E-mail: schejter@inidep.edu.ar
\end{abstract}

\begin{abstract}
In this contribution, we provide a list of the scleractinian corals recorded during the Argentinean Antarctic expeditions on board the oceanographic vessel Puerto Deseado (Argentina) in the austral summers in 2012, 2013 and 2014. The identified taxa consist of six solitary species (Flabellum impensum, F. flexuosum, $F$. areum, Caryophyllia antarctica, Paraconotrochus antarcticus and Javania antarctica), recorded from 19 sampling sites located off the Antarctic Peninsula and South Shetland and South Orkney islands. We also update the information of F. areum, previously known only from south-west Atlantic waters, extending its distribution range to Antarctic waters and its upper bathymetric range to $218 \mathrm{~m}$.

To access the supplementary material for this article, please see the supplementary files under Article Tools, online.
\end{abstract}

The term "coral" is a polyphyletic concept to group seven different cnidarian taxa (Scleractinia, Antipatharia, Octocorallia, Stylasteridae, Milleporidae, two zoanthids and three calcified hydractiniids) having continuous or discontinuous calcium carbonate or horn-like skeletal elements (Cairns 2007). Cold-water corals are organisms under the spotlight of international conservation organizations and national governments across the world (Roberts \& Cairns 2014). Corals are conspicuous components of the Antarctic benthos, although they do not usually constitute a high biomass of the benthic community, which is mainly dominated by sponges, echinoderms, tunicates and bryozoans (Brey \& Gerdes 1997). Among them, Antarctic scleractinians are well-studied organisms that comprise about 17 species distributed mostly off continental Antarctica and the Antarctic archipelagos (Cairns 1982, 1990). Additional species have been recorded and described for sub-Antarctic waters in southern South America, Drake Passage and New Zealand (Cairns 1982, 1995, 2007; Cairns \& Polonio 2013; Margolin et al. 2014).

The aim of this contribution is to provide a list of the scleractinian corals recorded during Argentina's recent
Antarctic expeditions in the austral summers, during three research cruises developed during February and March of 2012, January and February of 2013 and February and March of 2014 in the area comprised by the Antarctic Peninsula, South Shetland and South Orkney Islands. The geo-referenced data we present could contribute to global databases and to marine biodiversity inventories. Additionally, we update descriptive information and the distribution range of the cold-water coral Flabellum (F.) areum, previously recorded only from sub-Antarctic waters.

\section{Methods}

Specimens from a total of 47 sampled stations (Fig. 1) from three Antarctic expeditions on board the oceanographic vessel Puerto Deseado (Argentina) were studied. A demersal bottom trawl pilot net (6 $\mathrm{m}$ total length, $25 \mathrm{~mm}$ mesh on wings and $10 \mathrm{~mm}$ in the cod end) was employed, except at three sites at which a Blake trawl was used (in 2012). The sampling design and methods were not established for coral sampling procedures. This research is a by-product of general sampling designed for the characterization of demersal fish and macro- and megabenthos. 


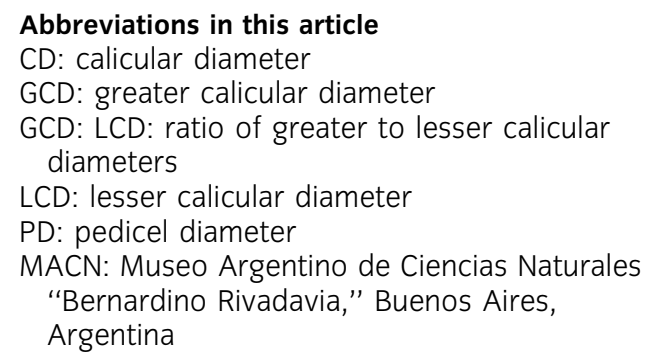

Scleractinian corals were sampled and separated from total catches, except at five stations, where the biomass of the total catch exceeded $150 \mathrm{~kg}$. At these five stations the majority of the benthic organisms was subsampled. Specimens were photographed and preserved on board, and subsequently transported, cleaned and identified at the Benthos Laboratory of the National Institute for Fisheries Research and Development (Instituto Nacional de Investigación y Desarrollo Pesquero), Argentina. Selected organisms were deposited as voucher specimens at MACN (the Supplementary file lists expedition codes). Specimens were identified considering the following sources: Cairns (1982, 1990), Cairns \& Kitahara (2012) and Cairns \& Polonio (2013).

\section{Results and discussion}

Scleractinian corals were recorded from 19 of the 47 sampling stations (Fig. 1, Table 1). Total catches per station varied from $1.63 \mathrm{~kg}$ to $547 \mathrm{~kg}$. A total of 250 living specimens belonging to five solitary species and one additional dead specimen of a sixth species were recovered from the catches. Five are common deep-sea species previously recorded for Antarctic waters (Cairns 1982, 1990), whereas one species represents a new record for Antarctic waters, also collected at its shallowest bathymetric range.

Phylum Cnidaria

Class Anthozoa

Subclass Hexacorallia

Order Scleractinia

Family Caryophylliidae

Genus Caryophyllia Lamarck, 1801

Caryophyllia (Caryophyllia) antarctica Marenzeller, 1904

Material examined. A total of 93 living specimens were recovered in the Antarctic Peninsula and South Orkney Islands at six stations during the three expeditions (Table 1, Figs. 2a, b, 3b). Deposited vouchers: MACN-In 40275, MACN-In 40278, MACN-In 40287.

Remarks. This was the second most abundant scleractinian species collected (after Flabellum impensum). The specimens had a conical corallum and a round calice, the largest specimen measuring $17 \mathrm{~mm}$ in CD and $26 \mathrm{~mm}$ tall, having 84 septa and 14 palar laths. The CD range of the studied specimens was $8-17 \mathrm{~mm}$. The specimens presented the characteristic sinuous septal and palar edges, with rectangular granules and short carinae. This Antarctic species was recently recorded from South American waters (Cairns \& Polonio 2013), between 87 and $1620 \mathrm{~m}$.

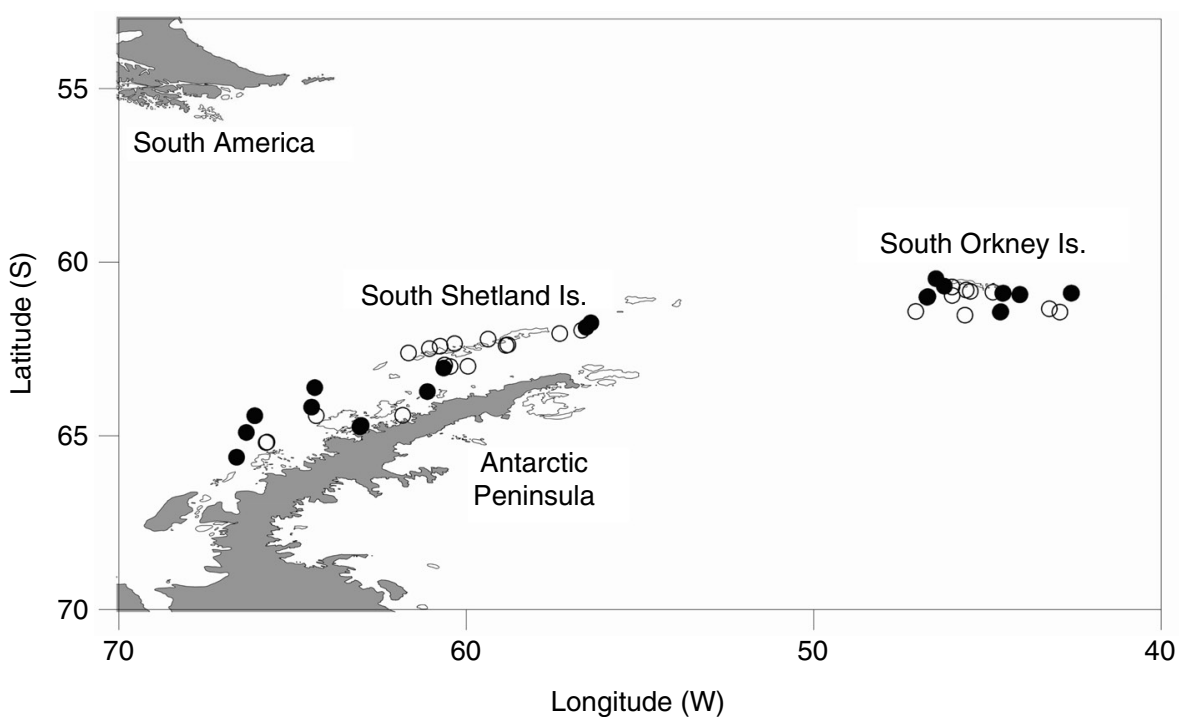

Fig. 1 Sampling stations of the 2012, 2013 and 2014 Argentinean Antarctic Expeditions. Scleractinian corals were collected only at the stations marked with black circles. 
Table 1 Location of the 19 stations where scleractinian corals were collected during the three Antarctic Argentinean expeditions in 2012, 2013 and 2014. Date of collection, latitude, longitude, depth, species identification and number of specimens (in parenthesis) are provided for each site.

\begin{tabular}{|c|c|c|c|}
\hline Date & Lat. (S), long. (W) & Depth (m) & Species recorded \\
\hline $20 / 02 / 12$ & $64^{\circ} 24,74^{\prime}, 66^{\circ} 05,42^{\prime}$ & 327 & Caryophyllia antarctica (2), Flabellum areum (2), F. impensum (2) \\
\hline 07/03/12 & $60^{\circ} 40,99^{\prime}, 46^{\circ} 14,56^{\prime}$ & 104 & F. impensum (6) \\
\hline $20 / 02 / 12$ & $64^{\circ} 53,63^{\prime}, 66^{\circ} 20^{\prime}$ & 404 & C. antarctica (1), F. areum (1) \\
\hline $22 / 02 / 12$ & $64^{\circ} 09,94^{\prime}, 64^{\circ} 27,25^{\prime}$ & 565 & juveniles Flabellum sp. (7) \\
\hline $22 / 02 / 12$ & $63^{\circ} 36,18^{\prime}, 64^{\circ} 21,80^{\prime}$ & 355 & C. antarctica (4) \\
\hline 23/02/12 & $63^{\circ} 43,09^{\prime}, 61^{\circ} 07,40^{\prime}$ & 142 & C. antarctica (1) \\
\hline 05/02/13 & $61^{\circ} 44,30^{\prime}, 56^{\circ} 25^{\prime}$ & 590 & F. impensum (1) \\
\hline 05/02/13 & $61^{\circ} 51,80^{\prime}, 56^{\circ} 33,10^{\prime}$ & 595 & F. impensum (8) \\
\hline $10 / 02 / 13$ & $63^{\circ} 02,40^{\prime}, 60^{\circ} 39,10^{\prime}$ & 132 & F. impensum (4) \\
\hline $13 / 02 / 13$ & $65^{\circ} 36,50^{\prime}, 66^{\circ} 36,80^{\prime}$ & 168 & $\begin{array}{l}\text { C. antarctica (2), Paraconotrochus antarcticus (1), F. flexuosum (2), } \\
\text { F. impensum (1), Flabellum sp. (2) }\end{array}$ \\
\hline $16 / 02 / 13$ & $64^{\circ} 43,80^{\prime}, 63^{\circ} 03,80^{\prime}$ & 318 & $\begin{array}{l}\text { F. areum (2), F. flexuosum (4), F. impensum (7), broken Flabellum sp. } \\
\text { (2) }\end{array}$ \\
\hline $16 / 02 / 13$ & $64^{\circ} 41,50^{\prime}, 63^{\circ} 01,60^{\prime}$ & 343 & F. areum (1), F. flexuosum (2) \\
\hline $19 / 02 / 14$ & $60^{\circ} 28^{\prime}, 46^{\circ} 29^{\prime}$ & 139 & F. impensum (42) \\
\hline 05/03/14 & $60^{\circ} 59^{\prime}, 46^{\circ} 43^{\prime}$ & 307 & F. impensum (1), juveniles Flabellum sp. (5), broken Flabellum sp. \\
\hline $10 / 03 / 14$ & $60^{\circ} 53^{\prime}, 42^{\circ} 35^{\prime}$ & 487 & $\begin{array}{l}\text { C. antarctica (84), P. antarcticus (1), F. flexuosum (4), F. impensum } \\
\left.\text { (4), Javania antarctica (1 } 1^{\mathrm{a}}\right)\end{array}$ \\
\hline $20 / 02 / 14$ & $60^{\circ} 53^{\prime}, 44^{\circ} 33^{\prime}$ & 218 & F. areum (1), F. impensum (17), juveniles Flabellum sp. (2) \\
\hline $02 / 03 / 14$ & $60^{\circ} 55^{\prime}, 44^{\circ} 04^{\prime}$ & 256 & F. flexuosum (1), F. impensum (3) \\
\hline 03/03/14 & $61^{\circ} 25^{\prime}, 44^{\circ} 37^{\prime}$ & 290 & F. impensum (9) \\
\hline 03/03/14 & $61^{\circ} 00^{\prime}, 46^{\circ} 44^{\prime}$ & 609 & F. impensum (2), broken Flabellum sp., juveniles Flabellum sp. (5) \\
\hline
\end{tabular}

${ }^{\mathrm{a} D e a d}$ specimen when collected

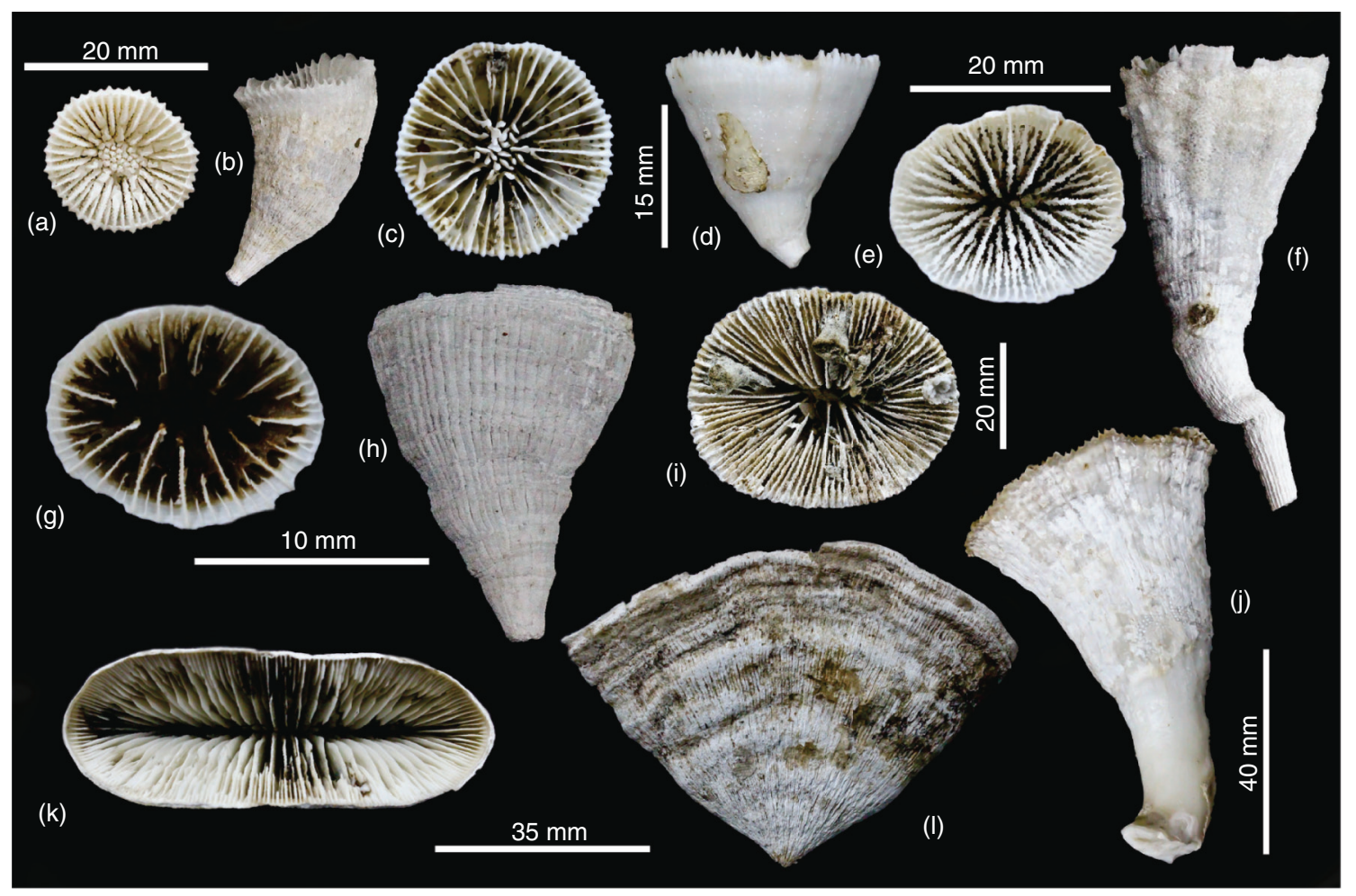

Fig. 2 (a, b) Caryophyllia antarctica; (c, d) Paraconotrochus antarcticus; (e, f) Flabellum flexuosum; (g, h) F. areum; (i, j) Javania antarctica; (k, l) F. impensum. 
See Cairns $(1982,1990)$ for a complete description of the species.

Genus Paraconotrochus Cairns \& Parker, 1992

Paraconotrochus antarcticus (Gardiner, 1929)

Material examined. Two living specimens were recorded from the Antarctic Peninsula and South Orkney Islands at two stations (Table 1, Figs. 2c, d, 3d). Deposited voucher: MACN-In 40293.

Remarks. The specimen deposited at MACN was collected at the South Orkney Islands. It was conical, with a round calice of $23 \mathrm{CD}$, and was $24 \mathrm{~mm}$ tall. It had 92 septa and a typical columella composed of many flattened laths. Live bryozoans and a lepadomorph crustacean were attached to it. The second specimen, which was collected off the Antarctic Peninsula, was not available for this study, although we have photographs of it. A complete description of the species and remarks on its biology are given by Cairns $(1982,1990)$. Its known bathymetric range is between 87 and $728 \mathrm{~m}$.

Family Flabellidae

Genus Flabellum Lesson, 1831

Flabellum (Flabellum) areum Cairns, 1982

Material examined. Seven living specimens (one broken and six complete specimens) were recorded at five stations located at the west of the Antarctic Peninsula and South Orkney Islands (Table 1, Figs. 2g, h, 3e, 4). Deposited vouchers: MACN-In 40276, MACN-In40282, MACN-In 40288, MACN-In 40303.

Diagnosis. The specimens have a trochoid morphology, having a PD between 2.5 and $4 \mathrm{~mm}$. The largest specimen measured $59 \mathrm{~mm}$ tall and the smallest, $25 \mathrm{~mm}$. They presented a GCD: LCD ratio between 1.25 and 1.35 (23:17, $39: 29,42: 33,29: 23$ and 20:16 in the complete specimens), and had between 62 and 104 septa, depending on size.

Remarks. The sizes of only two of our specimens lay within the known range for the species; the other complete specimens were larger than those previously

(b)

(a)
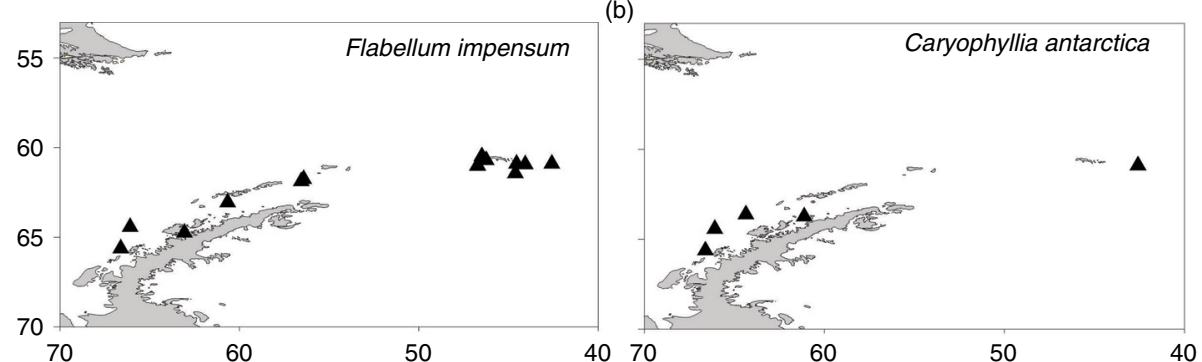

(c)
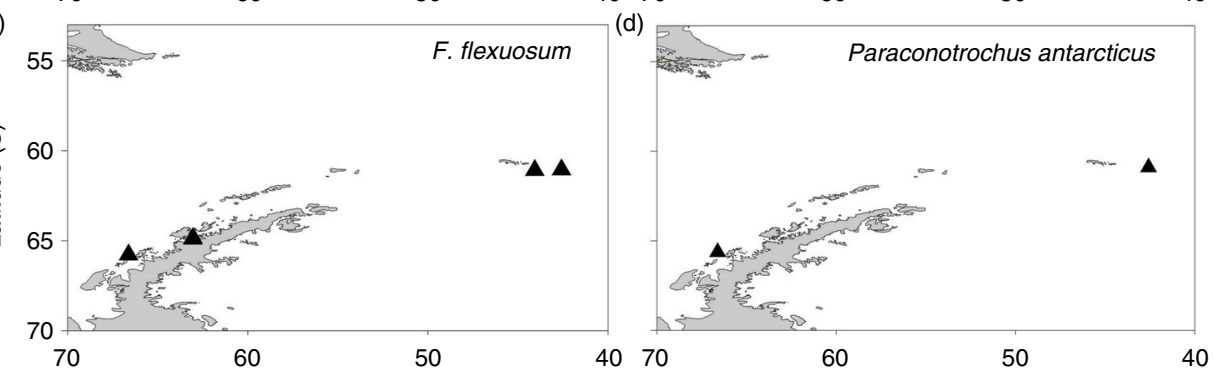

(e)
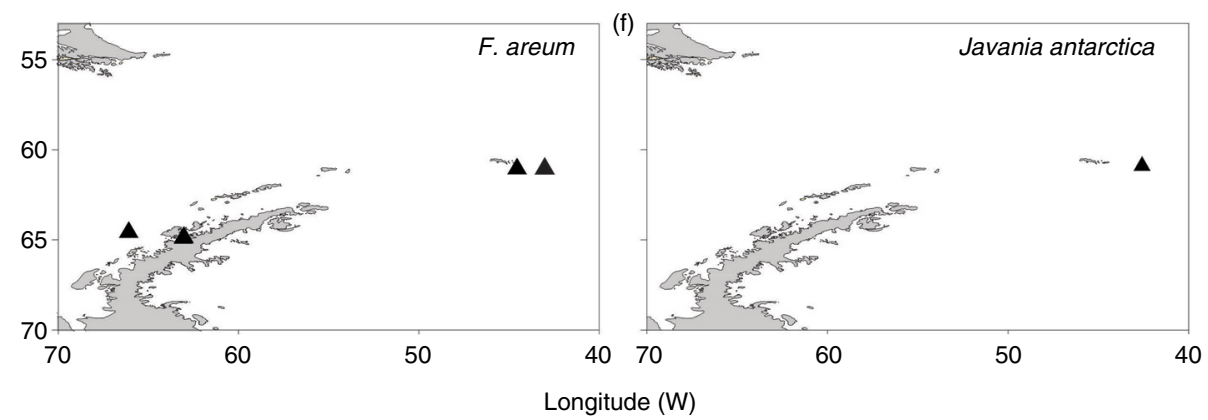

Fig. 3 Collection sites of the scleractinian species studied: (a) Flabellum impensum; (b) Caryophyllia antarctica; (c) F. flexuosum; (d) Paraconotrochus antarcticus; (e) F. areum; (f) Javania antarctica. 


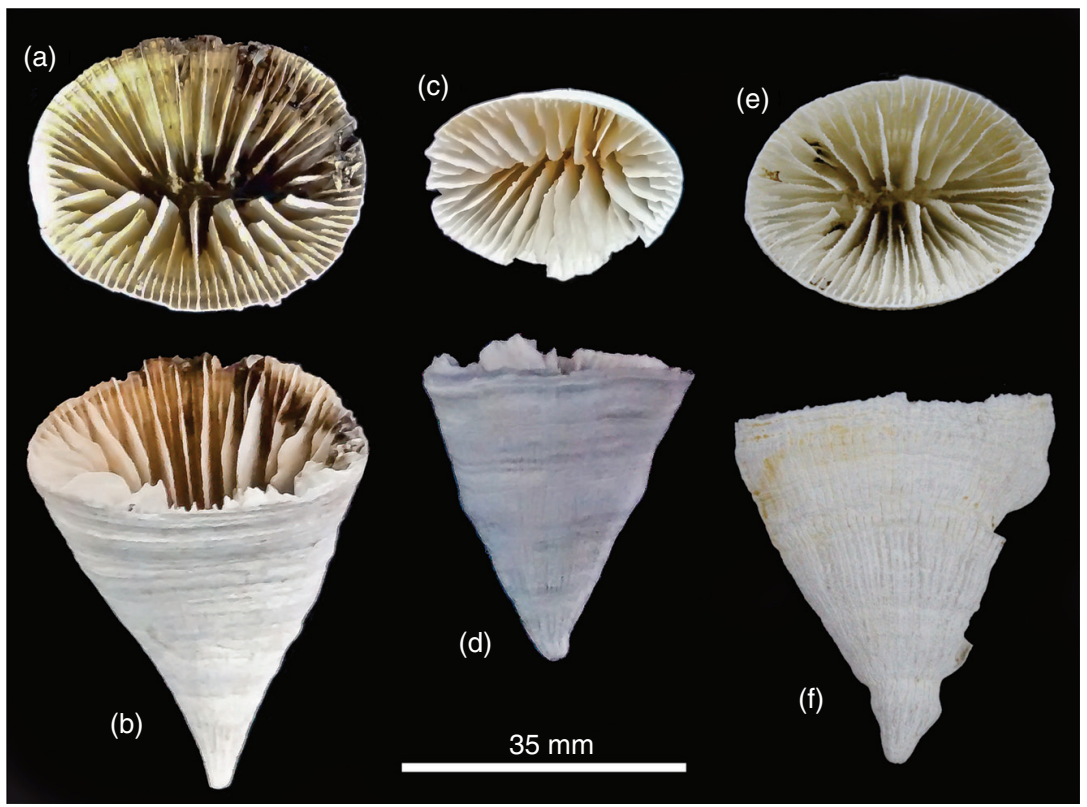

Fig. 4 Specimens of Flabellum areum of bigger sizes than previously recorded.

reported (Fig. 4). The species resembles F. thouarsii Milne Edwards \& Haime 1848 and F. curvatum Moseley 1881 (both species recorded only in the south-west Atlantic Ocean and in sub-Antarctic waters), as previously noted by Cairns (1982) and Cairns \& Polonio (2013), but can be distinguished from them by its widely spaced septa and its deeper fossa.

Distribution. The species has previously been recorded in the area between Mar del Plata and the Malvinas Islands (off Argentina), beyond the shelf break and near Tierra del Fuego (Cairns 1982; Cairns \& Polonio 2013). The bathymetric range of the five stations in which $F$. areum was recorded varied between 218 and $404 \mathrm{~m}$, all of them shallower than the shallowest limit of $749 \mathrm{~m}$ recorded in Cairns \& Polonio (2013). Our findings thus extend the distribution range of the species to Antarctic waters (up to $64^{\circ} 53,63^{\prime} \mathrm{S}$ ), and our record of a specimen collected at $218 \mathrm{~m}$ depth from a station near South Orkney Islands (Table 1) is the shallowest for the species.

Flabellum (Flabellum) flexuosum Cairns, 1982

Material examined. Thirteen specimens were recorded at five stations at the Antarctic Peninsula and South Orkney Islands during the 2013 and 2014 expeditions (Table 1, Figs. 2e, f, 3c). Deposited vouchers: MACN-In 40279, MACN-In 40281, MACN-In 40290, MACN-In 40291.

Remarks. The recorded specimens have the typical tall and conical morphology, although some of them were broken. The largest specimen measured was $51 \mathrm{~mm}$ tall, had 100 septa and a PD of $4 \mathrm{~mm}$, and had a GCD:LCD of $1.28(27: 21)$. Some of the specimens had bryozoans colonies and serpulid tubes encrusting the theca. The species was recorded from its known bathymetric (101$659 \mathrm{~m})$ and geographic range in Antarctica. See Cairns $(1982,1990)$ for a complete description of the species.

Flabellum (Flabellum) impensum Squires, 1962

Material examined. A total of 107 adult specimens was sampled in 14 stations of the Antarctic Peninsula and the South Shetland and South Orkney Islands (Table 1, Figs. 2k, l, 3a). Deposited vouchers: MACN-In 40277, MACN-In 40280, MACN-In 40283, MACN-In 40284, MACN-In 40285, MACN-In 40289, MACN-In 40292.

Remarks. This was the most common and frequent species recorded during the three expeditions. We report the typical flabellate morphology as well as the ceratoid and trochoid morphologies. The largest flabellate corallum was $67 \mathrm{~mm}$ tall, had 232 septa, a PD of $3 \mathrm{~mm}$ and a GCD:LCD of 2.9 (96:33). Many of the sampled specimens had bryozoans colonies encrusting one or both sides of the theca. It is possible that many of the juveniles identified as Flabellum sp. at several stations may belong to this species. The species was recorded from its usual bathymetric $(46-2260 \mathrm{~m})$ and geographic range in Antarctica, and recently, it has also been collected from Argentinean coastal waters (Schejter \& Bremec 2015). For a complete description of this species, see Cairns $(1982,1990)$. 
Genus Javania Duncan, 1876

Javania antarctica (Gravier, 1914)

Material examined. A dead specimen of J. antarctica, typically ceratoid with a broken reinforced pedicel, was collected near the South Orkney Islands (Table 1, Figs. 2i, j, 3f). Deposited voucher: MACN-In 40286.

Remarks. The specimen presented a GCD:LCD ratio of 1.26 ( $53 \mathrm{~mm} \times 42 \mathrm{~mm}$ ) and was $82 \mathrm{~mm}$ tall, having about 84 septa. The species was recorded from its known bathymetric (53-1280 $\mathrm{m})$ and geographic range in Antarctica. For a complete description of this species, see Cairns (1982, 1990).

\section{Acknowledgements}

We wish to thank to the crew and participants of the Antarctic expeditions that collaborated during sampling procedures. This study was partially supported by the National Scientific and Technical Research Council (Consejo Nacional de Investigaciones Científicas y Técnicas), the Argentinean National Antarctic Direction, the National Institute for Fisheries Research and Development (Instituto Nacional de Investigación y Desarrollo Pesquero) and PICT 2013-0629 (to SL). This is INIDEP contribution no. 1948.

\section{References}

Brey T. \& Gerdes D. 1997. Is Antarctic benthic biomass really higher than elsewhere? Antarctic Science 9, 266-267.
Cairns S.D. 1982. Antarctic and Subantarctic Scleractinia. Research Series 34, 1-74.

Cairns S.D. 1990. Antarctic Scleractinia. Koenigstein: Koeltz Scientific Books.

Cairns S.D. 1995. The marine fauna of New Zealand: Scleractinia (Cnidaria: Anthozoa). New Zealand Oceanographic Institute Memoir 103. Wellington: National Institute of Water and Atmospheric Research.

Cairns S.D. 2007. Deep-water corals: an overview with special reference to diversity and distribution of deep-water scleractinian corals. Bulletin of Marine Science 81, 311-322.

Cairns S.D. \& Kitahara M. 2012. An illustrated key to the genera and subgenera of the recent azooxanthellate Scleractinia (Cnidaria, Anthozoa), with an attached glossary. Zookeys 227, 1-47.

Cairns S.D. \& Polonio V. 2013. New records of deep-water Scleractinia off Argentina and the Falkland Islands. Zootaxa $3691,58-86$.

Margolin A.R., Robinson L.F., Burke A., Waller R.G., Scanlon K.M., Roberts M.L., Auro M.E. \& van del Flierdt T. 2014. Temporal and spatial distributions of cold-water corals in Drake Passage: insights from the last 35,000 years. Deep-Sea Research Part II 99, 237-248.

Roberts J.M. \& Cairns S.D. 2014. Cold-water corals in a changing ocean. Current Opinion in Environmental Sustainability 7, 118-126.

Schejter L. \& Bremec C. 2015. First record and range extension of the Antarctic coral Flabellum (Flabellum) impensum in Argentinean coastal waters. Marine Biodiversity Records 8, e104, doi: http://dx.doi.org/10.1017/S1755267215000858 